IRA-International Journal of Management \& Social Sciences

ISSN 2455-2267; Vol.04, Issue 01 (2016)

Institute of Research Advances

http://research-advances.org/index.php/RAJMSS

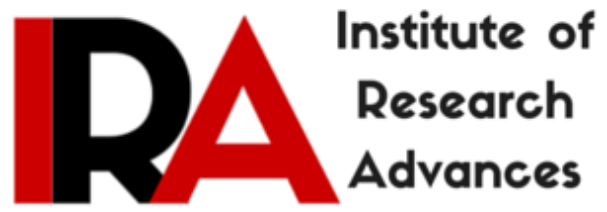

\title{
Development through MGNREGS: Cases from Nadia district of West Bengal
}

\author{
Dr. Shankar Chatterjee \\ Professor \& Head (CPME) \\ NIRD \& PR, Rajendranagar, \\ Hyderabad-500 030 \\ Telangana, India.
}

DOI: http://dx.doi.org/10.21013/jmss.v4.n1.p7

How to cite this paper:

Chatterjee, S. (2016). Development through MGNREGS: Cases from Nadia district of West Bengal. IRA-International Journal of Management \& Social Sciences (ISSN 24552267), 4(1). doi:http://dx.doi.org/10.21013/jmss.v4.n1.p7

(C) Institute of Research Advances

(cc) EY-NC

This works is licensed under a Creative Commons Attribution-Non Commercial 4.0 International License subject to proper citation to the publication source of the work.

Disclaimer: The scholarly papers as reviewed and published by the Institute of Research Advances (IRA) are the views and opinions of their respective authors and are not the views or opinions of the IRA. The IRA disclaims of any harm or loss caused due to the published content to any party. 


\begin{abstract}
Mahatma Gandhi National Rural Employment Guarantee Scheme (MGNREGS) has changed the lives of rural people as it has been creating assets as well as generating work for the rural residents. By converging with other schemes like Indira Awaas Yojana (IAY)/ Pradhan Mantri Awaas Yojana (PMAY) and also with other schemes, MGNREGS has created sustainable assets vis-à-vis generated employment for local residents with enhancing of purchasing power. In this article few cases pertaining to MGNREGS from Birohi-II Gram Panchayat of Haringhata block and one from Chakdah block of Nadia district, West Bengal are presented. The study was carried out in June 2016.
\end{abstract}

Key words: Convergence, House, Road, MGNREGS \& Nadia

In view of the serious unemployment in rural areas of India, Government of India has initiated a wage employment programme by passing an Act in the Parliament on $7^{\text {th }}$ September, 2005 which is known as Mahatma Gandhi National Rural Employment Guarantee Act (MGNREGA) and as scheme known as National Rural Employment Guarantee Scheme (MGNREGS). The key achievements of the MGNREGS since inception to 2014-15 (till 31 ${ }^{\text {st }}$ Dec. 2014) are as follows (Annual Report, 14-15):

- Employment Generated: in 2014-15, 3.60 crore households were provided employment and 121.25 crore person-days of employment were generated.

- Increased outreach to the poor and marginalized: Self targeting in nature, the programme had high work participation from marginalized groups like SC/ST (40\%), Women (56\%)

- Strengthening Natural Resource Base: In 2014-15, 95.14 lakh works were undertaken (spill over + new works), of which $31 \%$ for water conservation, $14 \%$ for the provision of irrigation facility on land owned by SC/ST/BPL and IAY beneficiaries, $14 \%$ for rural connectivity and $6 \%$ for land development.

The Government has taken a series of steps for improving quality of planning, durability of assets, particularly those aimed at enhancing agricultural production and productivity by encouraging convergence and curbing corruption under MGNREGA, such as:-

- To ensure correct identification of assets through scientific planning, an Intensive Participatory Planning Exercise (IPPE) was launched in 2500 backward blocks in July 2014. This would bring greater participation and scientific methods in planning of works;

- A clear 'Outcome Orientation' has been brought in the execution of works and measurement of outcomes after execution of work has been made mandatory, since August 2014;

- Schedule I to MGNREG Act, 2005 has been modified on $21^{\text {st }}$ July, 2014 providing that at least $60 \%$ of the works being taken in a district in terms of cost shall be for creation of productive assets directly linked to agriculture. This measure will create irrigation sources, promote water conservation and improve soil fertility;

- In order to allow creation of durable assets, the 60:40 ratio of labour to material will be maintained at the district level instead of block level for the works executed by implementing agencies other than Gram Panchayats;

With the launching of MGNREGS, not only employment opportunities are being generated but community assets are also being created. Thus through employment generation, economy is gaining by "Multiplier Effect" vis-à-vis community assets have been helping for the development of environment as most of the works are pertaining to water related activities.

In this paper few cases pertaining to MGNREGS benefitting rural households are presented. The cases pertain to Birohi-II Gram Panchayat of Haringhata block Nadia district, and one case is from Chakdah block, Nadia district, West Bengal. The study was carried out in 2016, June. 


\section{About Nadia District:}

The district Nadia is situated between $22^{\circ} 53^{\prime \prime}$ and $24^{\circ} 11^{\prime \prime}$ North latitude and $88^{\circ} 09^{\prime \prime}$ and $88^{\circ} 48^{\prime \prime}$ East longitude and spread over to an area of about 3927 square kilometres. The district is roughly 46 feet above the mean sea level. The Tropic of Cancer has divided the district in two parts. Total population as per 2011 census was 46,04,827 of which rural population was 36,25,308 ( $78 \%$ ) with density of population 1172 persons per square kilometres and sex ratio was 946 . The entire district lies in the alluvial plain of the Ganga and its tributaries. The district is having 17 Panchayat Samities (block level panchayat) consisted of 187 Gram Panchayats (nadia.gov.in).

The cases benefiting rural persons through MGNREGS are given below:

\section{Case-1: IAY house}

Ms. Sargis Bibi of Narayanpur village, Narayanpur - X of gram sansad was provided with a house under India Awaas Yojana (IAY) in September 2015. Regarding gram sansad, it is pertinent to mention that 'the West Bengal Panchayat Amendment Act 1994 has elaborately discussed about the Gram Sansad and Gram Sabhas. According to this Act, for each constituencies of the Gram Panchayat there will be one Gram Sansad and all voters of that constituency are the members of this Gram Sansad'. Further, the Gram Sansad 'has to look after many things like, giving importance for implementing various projects maintenance for the overall economic development of the region, to give opinions about various developmental projects for establishing social justice, to materialize different projects and to ascertain popular participation in its maintenance and equal distribution by establishing the beneficiary committees empowered to look after it, to preserve and maintain integrity and consolidation among the people of the region, and to create popular initiative for implementing various positive programme to ensure social welfare, to evaluate or criticize the attitude of indifference or negligence on the part of the Panchayat Pradhan or other members of the Panchayat in developmental activities etc. (gram-sansad-west-bengal). However, in case of Ms. Sargis Bibi, before getting IAY house, her house was in shanty condition. In this case IAY fund and MGNREGS fund were converged to the total tune of Rs. 85,660 - Rs. 70,000 IAY share and MGNREGS fund of Rs.15,660 and thus total cost of the house was Rs.85,660. It is may be noted that under MGNREGS, she and other members of the family worked and earned an amount of Rs.15,660 by working 90 days. Such type of convergence may be replicated in other parts of the country.

\section{Case-2: IAY house}

Ms. Togli Bibi and her family members today are happy as she was provided with pucca house in September 2015, under IAY. She is the resident of Narayanpur - X gram sansad and like Ms. Sargis Bibi she was provided with IAY house with a sum of Rs.85,660 where share of IAY was Rs.70,000 ( as per norm of then IAY) and the balance amount of Rs.15,660 was spent from MGNREGS fund. By working 90 days under MGNREGS, the family was benefitted in two ways got a pucca house and earned Rs.15,660 in one year.

\section{Case - 3: IAY house}

Another happy woman of Narayanpur - X, gram sansad of Narayanpur village, Birohi II, Gram Panchayat is Ms. Asura Bibi. She earlier had a dilapidated house. In November 2014, she was provided with a house by converging IAY and MGNREGS. Like others in this case also she along with her family got 90 days' work under MGNREGS and earned a sum of Rs.15,660 for constructing IAY house which in addition to Rs. 15,660 was Rs.70,000. Thus with total spending of Rs.85,660, the family got a pucca house where all the family members were staying happily.

\section{Case-4: Link Road under MGNREGS:}

A pucca road at Birohi II Gram Panchayat of Narayanpur - X, gram sansad was constructed in February 2016, under MGNREGS from the house of Sri Sadananda Singha to the house of Sri Manoranjan Sarkar. This 153 meters pucca road has changed the lives of local residents as earlier road was literally not functional. The residents of area were mostly minority (Muslim) and Scheduled Caste and again many of them eke out their livelihood by working as agricultural labour so the road 
greatly helped them to move easily from one place to another. While constructing the road, local villagers were involved and a sum of Rs.19,140 was earned by them by working as MGNREGS worker which generated 110 man-days.

\section{Case-5: Link Road under MGNREGS:}

A road at Birohi-II Gram Panchayat of Narayanpur - IX gram sansad was constructed in 2015, November under MGNREGS with a sum of Rs.4,109,60 by generating total number of mandays of 2872. It was an earthen road with a total length of 1.3 Kilometre constructed from the house of Prankrishna Sarkar to the point of Jamuna river connected three villages. The villagers of the locality were very poor and belonged to minority and SC community and their main source of livelihood was earning as agricultural labour. So the road helped them to move freely. The villagers suggested that the road may be converted into concrete one in future for its sustainability as many persons take their agricultural goods to local market.

\section{Case-6: Fishery Project at Chakdah under self-help Group:}

This unique project developed under MGNREGS is from Tangra village, Dubra Gram Panchayat of Chakdah block. The fishery project for rearing of cat fish was developed under MGNREGS where 10 Muslim women of Below Poverty Line (BPL) households formed Unnati self-help groups (SHG) in December 2015. They came to know about cat fish cultivation in 2014 and accordingly trained in that year by the Fisheries Department of Chakdah Development Block. And in the process local village panchayat also cooperated as they endorsed the training. It is pertinent to mention that fish is an important food of Bengalis irrespective of caste and religion. Almost all the Bengali people along with rice enjoy fish both in lunch and dinner which is popularly known as 'Maach-Bhaat' (fish curry and rice). From this point of view fish is having huge market all over the West Bengal and also in neighboring states.

At the very beginning the SHG members acquired a land of 0.25 acre on lease and subsequently under MGNREGS seven small tanks were excavated on the land for rearing of fish, fingerling to table fish, in the year 2015 by incurring a sum of Rs. 1,47,899 from MGNREGS fund. Later on, they used their own corpus fund for other expenditure. This project brought lot of changes in the economic life of the BPL households. While visit was made on $21^{\text {st }}$ June 2016, the SHG members informed that they were provided with a sum of Rs 1 lakh as bank loan from local Regional Rural Bank (RRB) in the first week of June 2016 which they would use for nurturing of fishes as raw materials etc. The initiative of block and the project cost may be seen as below:

\section{Initiative of the Block:}

The data provided by the block officials evince that Chakdah Block had implemented 210 small farm ponds (as mentioned already) with an expenditure of Rs. 44.37 Lakh on unskilled wages (23790 person-days) in two financial years - 2014-15 and 2015-16. Finally, 210 vulnerable households were benefited as net profit accrued was to the tune of Rs. 53600.00 per family per year from these projects only. The project cost incurred under MGNREGS at Tangra village, Dubra Gram Panchayat of Chakdah block is given below:

\begin{tabular}{|cc|}
\hline MGNREG Scheme Details : For 7 numbers of farm ponds \\
Total wage COST & : Rs. 137982.00 \\
Total materials COST & : Rs. 9917.00 \\
Total project cost & $:$ Rs. 147899.00 \\
Total Person-days generated & $: 793$ \\
\hline
\end{tabular}

Source: Chakdah Development Block, Nadia district, West Bengal

\section{Factors behind implementing the project:}

The study reveals all the stakeholders (members of self-help groups) were from below poverty line households even managing two square meals in a day was an issue for them. For example, it was 
really a tough time for Sarifa Mondal when her only child was severely ill but no money was available to treat him. After joining in the SHG things improved to a great extent which can be termed as worst to good. Same case was Marjina Bibi Mondal as she also had encountered almost same situation while arranging marriage of her daughter. It was always the poverty which restricted them from fulfilling their necessity and achieving their dreams. This was not the story of only these two women but reality was in every household of village Tangra of Dubra Gram Panchayat i.e. lack of minimum money to sustain a family. While cat fish cultivation was taken up situation improved to a great level as both backward and forward linkages were favourable to the project. The fingerling of cat fish was available locally as well as the feed and medicines.

Before starting the project, the group members initiated process of market survey and observed that there was a market demand for cat fish as people were ready to purchase their product so with great hope, hype and hoopla they initiated the project.

\section{Profit:}

These data pertaining to SHG's contribution and profit analysis have been provided by the Officials of MGNREGS of Chakdah Development Block.

The data provided by the officials reveal the fact that within a year the total expenditure incurred for the project was to the tune of Rs. 8.5 lakh (in five phases) and yielded a net return of 10,500 kilograms cat fish with a total income of Rs. 13.86 lakh (in five phases) and thus the members of SHG earned a net profit of Rs. 5.36 lakh. Each of the ten members who were involved in this project earned at the rate of Rs. 53,600 a year. In addition, by working as MGNREGS labour they could earn some additional income as the project of MGNREGS generated 793 person-days.

\begin{tabular}{|c|c|}
\hline $\begin{array}{ll}\text { SHG's Contribution For one cycle (45 days) } \\
\text { - } \quad \text { For fingerling : Rs. } 45,000.00 \text { (3 lakh } \\
\text { numbers) } \\
\text { - } \quad \text { For land : Rs. } 10,000.00 \\
\text { - } \text { For Electricity : Rs.5,000.00 } \\
\text { - For Labour : Rs. } 10,000.00 \\
\text { - } \quad \text { For Feed : Rs.1,00,000.00 } \\
\text { - Others : Rs.5,000.00 } \\
\text { - Total: Rs.1.70 Lakh }\end{array}$ & $\begin{array}{l}\text { Cost-Benefit Analysis } \\
\qquad \begin{aligned}> & \text { Total Expenditure : } 1.7 \text { lakh x } 5 \\
& \text { : Rs.8.5 lakh } \\
> & \text { Total Income: } 2100 \text { x } 5 \text { x 132: Rs. } 13.86 \\
& \text { lakh } \\
> & \text { Net profit: Rs. } 5.36 \text { lakh } \\
> & \text { Net Profit per family per year: Rs. } \\
& 53600.00\end{aligned}\end{array}$ \\
\hline
\end{tabular}

Source: Chakdah Development Block, Nadia district, West Bengal

\section{Social impact:}

The project not only left its impression for sustaining economic prosperity of the SHG members but also had an impact on social life of villagers as it epitomized as 'Demonstration Effect', as two SHGs immediately took up the activity and later seven more SHGs came forward in cat fish rearing as project. Further, undoubtedly the project has improved the SHG members' families with better nutrition, enhanced scope of education of their children etc. and thus improved in quality of life.

Conclusion: The above discussion reveals that the village panchayat by implementing MGNREGS work had improved economic life of the poor villagers. In case of convergence of MGNREGS with IAY is unique and road had improved quality of life and fishery project improved economic condition of the villagers. Such projects may be replicated in other parts of the country by keeping in mind with local socio-cultural condition.

\section{Acknowledgement}

The author is thankful to the Block officials of Haringhata and Chakdah Blocks for providing necessary data and cooperating during the course of study. 


\section{Reference:}

1) Ministry of Rural Development, Government of India, “Annual Report, 2014-15”, New Delhi.

2) http://nadia.gov.in

3) http://www.importantindia.com/1972/gram-sansad-west-bengal/ 